\title{
An Overview of Mites on Grapevine and the Discovery of a New Phytoseiidae Species: Typhlodromus (Typhlodromus) spiceae
}

\author{
M. Vermaak ${ }^{1}$, E.A. Ueckermann ${ }^{2 *}$, R. Veldtman ${ }^{1,3}$, P. Addison ${ }^{1}$ \\ (1) Department of Conservation Ecology \& Entomology, Stellenbosch University, Private bag X1, Matieland 7602, South \\ Africa \\ (2) Unit for Environmental Sciences and Management, Potchefstroom Campus, North-West University, Private Bag X6001, \\ Potchefstroom 2520, South Africa, edalbert@lantic.net \\ (3) South African National Biodiversity Institute, Kirstenbosch Research Centre, Private Bag X7, Claremont 7735, South Africa
}

Submitted for publication: September 2020

Accepted for publication: March 2021

Key words: Phytoseiidae, Typhlodromus, biocontrol, mites, phytophagus

The European grapevine (Vitis vinifera L.) is the main species used for wine making, with South Africa being one of the top wine exporting countries. Grapevine is vulnerable to a range of pests, including mites. We present an overview of phytophagous and predatory mites on grapevine in South Africa and describe a new phytoseiid species which was discovered in the winelands region of Wellington, South Africa. Grapevine shoots with leaves were collected over two growing seasons at four farms in Wellington. A nursery, mother block and a commercial vineyard were selected on each farm. The mites were removed with a mite brushing machine and slide mounted. The Phytoseiidae Database, as well the most recent relevant literature were used in confirming the new species. Illustrations of the new species were made using photographs taken by Zeiss Axioskop TM Research that included a Zen Soft Imaging System. The new Typhlodromus species, Typhlodromus (Typhlodromus) spiceae sp.n., is set apart from closely related species by setae $Z 4$ being 0.7 times the length of $Z 5$ and by having a short, saccular and thick-walled spermathecal. This species was found together with one phytophagous mite species (Brevipalpus lewisi) and several predatory mite species (Typhlodromus praeacutus, Typhlodromus saevus, Eusieus addoensis). A key to identify females of the South African species of Typhlodromus (Typhlodromus) is provided.

\section{INTRODUCTION}

The European grapevine (Vitis vinifera L.) is the main species of grapevine used for wine making in South Africa. Grapevines are vulnerable to a range of pests, including mites. Mites are the most successful and diverse of the chelicerates (Walter \& Proctor, 2013). What makes a mite different to other Arachnida, is that its mouthparts are situated on a separate structure at the front of the body called the gnathosoma. The rest of the body is fused to form the idiosoma (Evans, 1992). Mites have evolved to feed on plants, fungi and bacteria, to being predators, saprophytes, parasites and symbionts (Krantz, 2009). With this, they have managed to occupy a wider range of habitats than any other arthropod group (Krantz, 2009). Their small body size allows them to easily disperse through air and wind currents, and also to be transported by larger animals, a process called phoresis (Krantz, 2009).

Mites occur in all habitats, they play an important role in ecology, and they are also a valuable component in human developments such as agriculture. Mites can be beneficial by preying on agricultural and ornamental crop pests (Gerson, et al., 2003), while non-predatory mites are effective nutrient recyclers. Many are highly detrimental as disease vectors to plants and animals and as serious pests of crops and ornamental plants (Krantz, 2009). Plant parasitism has evolved many times into different lineages of mites so that today the majority of monocotyledons, dicotyledons, coniferophyta and vascular plants are invaded by one or more species of mite (Jeppson et al., 1975; Helle \& Sabelis, 1985a, b; Lindquist et al., 1996). Mites attack many crops, including tropical fruit, deciduous fruit and grapevines, citrus, vegetables, tea, nuts, berries and stored products (Smith Meyer \& Craemer, 1999). Some phytophagous mites have also been established as effective weed biocontrol agents (Gerson, et al., 2003).

All the phytophagous mites in the Suborder Prostigmata feed only on fluids (Walter \& Proctor, 2013). Predatory Prostigmata have chelate chelicerae which they use to crush their prey to extract their fluids (Walter \& Proctor, 2013).

*Corresponding author: edalbert@atlantic.net

Acknowledgements: Winetech are thanked for funding this research; we are also thankful to the various growers who allowed us to use their vineyards. This work is based on the research supported in part by the National Research Foundation of South Africa (Grant Numbers 126938). Any opinion, findings and conclusions or recommendations expressed in the material are those of the authors and therefore the NRF does not accept any liability in regard thereto. 
The majority of plant feeding Prostigmata have stylet-like mouthparts, ideal for puncturing host plants (Lindquist, 1998) and sucking out plant fluids.

The aim of this article is to give an overview of mites on grapevine in South Africa, to provide context to the importance of predatory mites in viticulture and to describe a new Phytoseiid mite, belonging to the genus Typhlodromus Scheuten, found during a survey of mites on grapevines in the Western Cape.

\section{OVERVIEW OF MITES ON GRAPEVINES IN SOUTH AFRICA \\ Grapevine mite pests}

The most common grapevine mite is Colomerus vitis (Parenstecher), known as the grapevine budmite. Colomerus vitis has a vermiform body with only two pairs of legs. They cause erineum, abnormal hair growth, leaf curl and damage buds (Smith Meyer, 1981). Colomerus vitis consist of three physiological races which can only be distinguished by the damage they cause (Smith Meyer, 1981). Tetranychidae (spider mites) is a well-known agricultural pest, including on grapevine (Smith Meyer \& Craemer, 1999; Mani et al., 2014). Their mouthparts consist of a pair of elongate, extrusible cheliceral stylets (Hislop \& Jeppson, 1976). This allows them to puncture plant cells and absorb the leaf cell contents, which in turn, compromises the plant's ability to photosynthesize (Flaherty \& Wilson, 1999). Tetranychidae found on grapevine are Panonychus ulmi (Koch) (Smith Meyer, 1974; 1981; 1987; Jeppson et al., 1975; Annecke \& Moran, 1982; Pringle et al., 1986; Smith Meyer et al., 1990; Botha, 1993), Tetranychus urticae Koch, 1836 (Pringle et al., 1986; Walter et al., 2009) and Tetranychus ludeni Zacher (Smith Meyer \& Rodrigues, 1966; Coates, 1974; Smith Meyer, 1974; 1981; 1987; 1996; Jeppson et al., 1975; Duncombe, 1977; Annecke \& Moran, 1982; Botha et al., 1986; Smith Meyer et al., 1988; 1989; 1990; Du Toit, 1993). Tenuipalpidae are perfectly adapted to lie flat against plant surfaces. They damage their host by feeding and injecting toxic saliva into bud tissues, the epidermal cells of stems, leaves and fruit, thereby acting as vectors for plant viruses (Hao et al., 2016; Childers et al., 2003). Brevipalpus californicus (Banks), Brevipalpus obovatus Donnadieu (Smith Meyer \& Craemer, 1999) and Brevipalpus phoenicis (Geijskes) have been identified as grapevine pests in South Africa (Moutia, 1958; Jeppson et al., 1975; Smith Meyer, 1979; 1981; Smith Meyer et al., 1987; 1989; 1990; Smith Meyer \& Swartz, 1998).

\section{Phytoseiidae as biocontrol agents}

Phytoseiids are the best studied group of predatory mites due to their success in controlling mites, whiteflies (Hemiptera: Aleyrodidae) and thrips (Thysanoptera) (Gerson et al., 2003). Phytoseiids have been established as effective biocontrol agents for mites in many crops, including vineyards (McMurtry et al., 1970; Duso et al., 1994; McMurtry \& Croft, 1997; Croft, et al., 1998; Greco et al., 2005; Duso et al., 2012; Escudero \& Farragut, 2005; Fraulo \& Liburd, 2007). Specialist phytoseiid species aggregate in response to pest kairomores and plant volatiles emitted in response to herbivory (Sabelis \& Dicke, 1985; McMurty \& Croft, 1997).
They have the ability to quickly increase their population as a response to the infestations (McMurtry \& Croft, 1997; Croft et al., 2004). Generalist phytoseiids are considered a more sustainable approach for biological control (Ivancich Gambaro, 1973; McMurtry, 1992; James \& Whitney, 1993), due to specialists' tendency to over-populate and over-exploit the pest abundance, leading to emigration and starvation, thereby contributing to unstable prey-predator dynamics (McMurtry, 1992; Nyrop et al., 1998; Jung \& Croft, 2001). Generalists can move to an alternate food source when pests are absent (McMurtry, 1992; Duso et al., 2012), instead of migrating. However, generalist phytoseiids are susceptible to pesticides (James, 1990). Phytoseiids are also efficient at controlling eriophyid mites (also known as bud mites), because they are able to detect them from a distance via the volatiles emitted by infested plants (Dicke, 1988; Dicke et al., 1988; Aratchige et al., 2004; Liguori, 1988; Engel \& Ohnesorge, 1994a, b; Aratchige et al., 2004).

Several species of the genus Typhlodromus Scheuten are important predators of phytophagous mite populations in orchards and vineyards (Ivancich Gambaro, 1973; Girolami et al., 1992; Duso \& Pasqualetto, 1993; Duso \& Vettorazzo, 1999; Duso, et al., 2012; Tixier et al., 2013). Typhlodromus species vary between specialist and generalist predators (McMurtry \& Croft, 1997; McMurtry et al., 2013). Typhlodromus species are common predators on fruit crops, with some species being effective at controlling pests. Typhlodromus pyri Scheuten has been shown to regulate the European red mite (Panonychus ulmi (Koch) and the Apple rust mite (Aculus schlechtendali (Nalepa) on apple in New Zealand and the United Kingdom (Wearing et al., 1978; Solomon et al., 1993). Typhlodromus pyri in combination with various other predatory mites has also shown potential in controlling eriophyids and tetranychids in Italy (Duso, 1989; Duso \& Vettorazzo, 1999). Typhlodromus pyri is capable of surviving on alternate food sources like plant sap, fungi spores and pollen (Johnsen \& Hansen, 1986; Croft et al., 1995; Ripka, 1998, Pozzebon \& Duso, 2008; Pozzebon et al., 2009). Species of this genus form an important part of integrated pest management (IPM) programs (Croft, 1990; McMurtry \& Croft, 1997; Desneux et al., 2007). Typhlodromus exhilaratus Ragusa and Typhlodromus phialatus Athias-Henriot have been recognized as being effective at protecting vineyards in Southern Europe against plant feeding mites (Kreiter et al., 2000; De Moraes et al., 2004).

Predatory mites are considered an effective method for limiting mite outbreaks (Sentenac et al., 1993). Pesticides that kill beneficial predatory mites should only be considered as a last resort for pest control (Smith Meyer, 1996). Where mite pests are not effectively controlled by their natural enemies, integrated control can be implemented (Smith Meyer, 1996).

A major factor that leads to the use of phytoseiids as biocontrol agents in IPM and integrated mite control (IMC) programs, is the ability of spider mites to develop resistance to pesticides (Smith Meyer, 1996; McMurtry, 1982; Helle \& Sabelis, 1985a, b; Smith Mayer, 1996).

For the sustainable and efficient control of mites, it is crucial to positively identify each pest species, recognize 
the damage it causes, know its biology and life history and understand the seasonal occurrence and basic strategy required for its control (Smith Meyer, 1996).

\section{MITE COLLECTION}

Samples of grapevine, Vitis vinifera L. were collected on farms in the vicinity of Wellington $(-33.936179 ; 18.862899)$ in the Western Cape, South Africa during a survey on mite diversity in vineyards. Exact locations are withheld to protect the identity of the growers. Each farm contained a commercial vineyard, mother block and nursery. Ten random vine branches and sub-branches were collected at each block. Samples were separately packaged in sealed plastic bags, returned to the laboratory and kept in the refrigerator $\left(10^{\circ} \mathrm{C}\right)$ until further inspection.

In the laboratory the vine leaves were run through a mite brushing machine (Fig. 1); the machine (Leedom Engineering) has two brushes that comb the mites off the leaf onto a Perspex plate. The plate was then examined under a stereo microscope and mites were collected into $70 \%$ ethanol. Mites were cleared in lactic acid and slide mounted in PVA solution following the general protocols in Krantz $\&$ Walter (2009). Mites mounted on microscope slides were dried in an oven at $45-50{ }^{\circ} \mathrm{C}$ for 24 hours. The mites were identified using a compound microscope with phase contrast and measured with a Zeiss Image Analysing System, Zen 2.3 lite.

\section{DESCRIPTION OF A NEW PHYTOSEIIDAE SPECIES}

During the mite diversity survey, a new Phytoseiidae (genus Typhlodromus) species was found. Line drawings were made of the new species from photographs of the specimens taken with a Zeiss Axioskop TM Research microscope equipped with a Zen Soft Imaging System and measuring tools. All illustrations were edited using Adobe Illustrator C5. All measurements were in micrometers $(\mu \mathrm{m})$. Dimensions are listed for the holotype, with variations of paratypes in brackets. The Phytoseiidae database by Ferragut \& Ueckermann (2012), Stathakis et al. (2012), Demite, et al. (2014) and Tixier et al. (2016) were used in confirming the new species. The setal notations adopted were those of Lindquist \& Evans (1965), as adapted by Rowell et al.
(1978) for the dorsum. The idiosomal setal pattern follows Chant \& Yoshida-Shaul (1992).

Type specimens were deposited in the National Collection of Arachnida (NCA) in Pretoria, South Africa.

The family Phytoseiidae consists of 2521 species in 94 genera (Demite et al., 2020), representing 3 subfamilies. The new species belongs to the subfamily Typhlodrominae Wainstein with 732 described species in 23 genera and the genus Typhlodromus Scheuten consisting of two subgenera; Typhlodromus (Typhlodromus) and Typhlodromus (Anthoseius).

The subgenus Typhlodromus is defined as follows: Dorsal setae j1, j3, j4, j5, j6, J2, z2, z3, z4, z5, Z4, Z5, s4, s6, S2, S4, r3 and R1 present (S5 absent). Ventral setae JV1, JV2, JV3, JV4, JV5, ZV1, ZV2, ZV3 present. JV3 present or absent. Setae S5 are absent. Z4 and S4 are transversely aligned.

\section{Typhlodromus (Typhlodromus) spicae sp.n. \\ FEMALE $(\mathrm{N}=6)$ (Fig. 2):}

Dorsum (Fig. 2 (1); Table 1): Dorsal shield 322 (316 - 330) long and $162(160-181)$ wide. With 4 pairs of solenostomes. Idiosomal setal pattern 12A: 7A and JV: ZV (Chant \& Yoshida-Shaul, 1992). Setae ji $22(19-23)$, j3 $31(30-32)$, j4 16 (16 - 20), j5 16 (16 - 20), j6 22 (19-23), J2 20 (23 25), J5 5 (6-7), z2 22 (18 - 22), z3 26 (23 - 29), z4 24 (24 31), z5 19 (18 - 20), Z4 47 (47 - 55), Z5 69 (69 - 71), s4 30 $(31$ - 33), s6 35 (34 - 37), S2 39 (39-43), S4 41 (40 - 46), r3 $21(21-27)$, R1 30 (24 - 30). Setae serrate, except j1, $\mathrm{j} 4$, z5 smooth, and J5 and R1 sometimes smooth. Peritreme extending to level between $\mathrm{j} 3$ and $\mathrm{z} 2$.

Venter (Fig. 2 (2-3); Table 1): Sternal shield mostly smooth, with few lateral striae; posterior margin with medium lobe; distances between ST1 - ST2 31 (31 - 37), ST2 - ST2 57 (56-60). Genital shield smooth; distance between ST5 - ST5 54 (54 - 60). Ventrianal shield striate, pentagonal, with anterior margin straight, 96 (96-108) long, 84 (84 - 99) wide at level of ZV2, $77(74-88)$ wide at level of anus, pre-anal pores absent. Caudoventral setae JV5 smooth $60(54-63)$.

Spermatheca (Fig. 2 (4); Table 1): Calyx saccular with distal half thick walled 15 (15-16). Atrium incorporated in calyx.

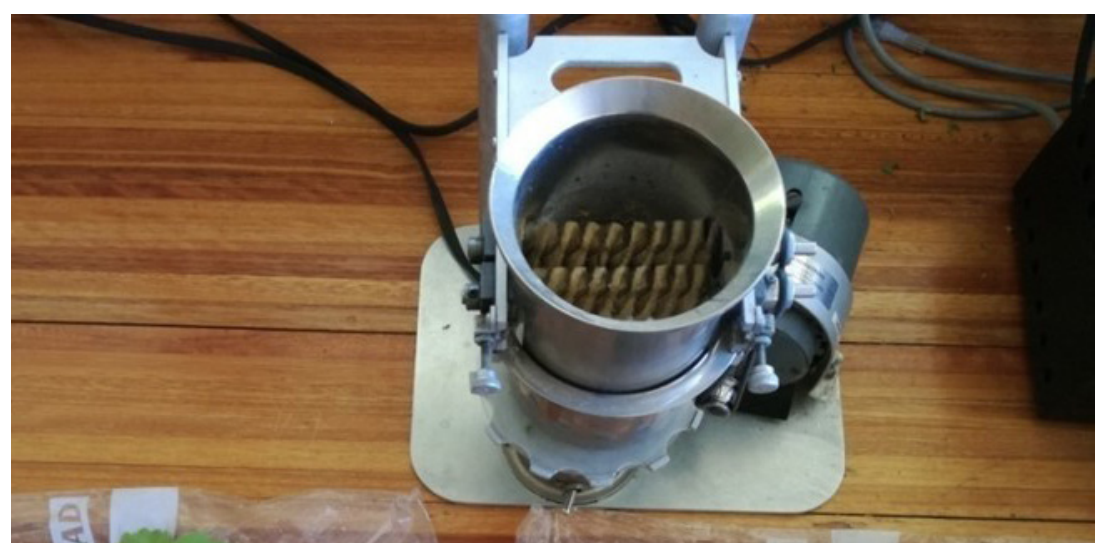

FIGURE 1

The Leedom engineered leaf brushing machine. 

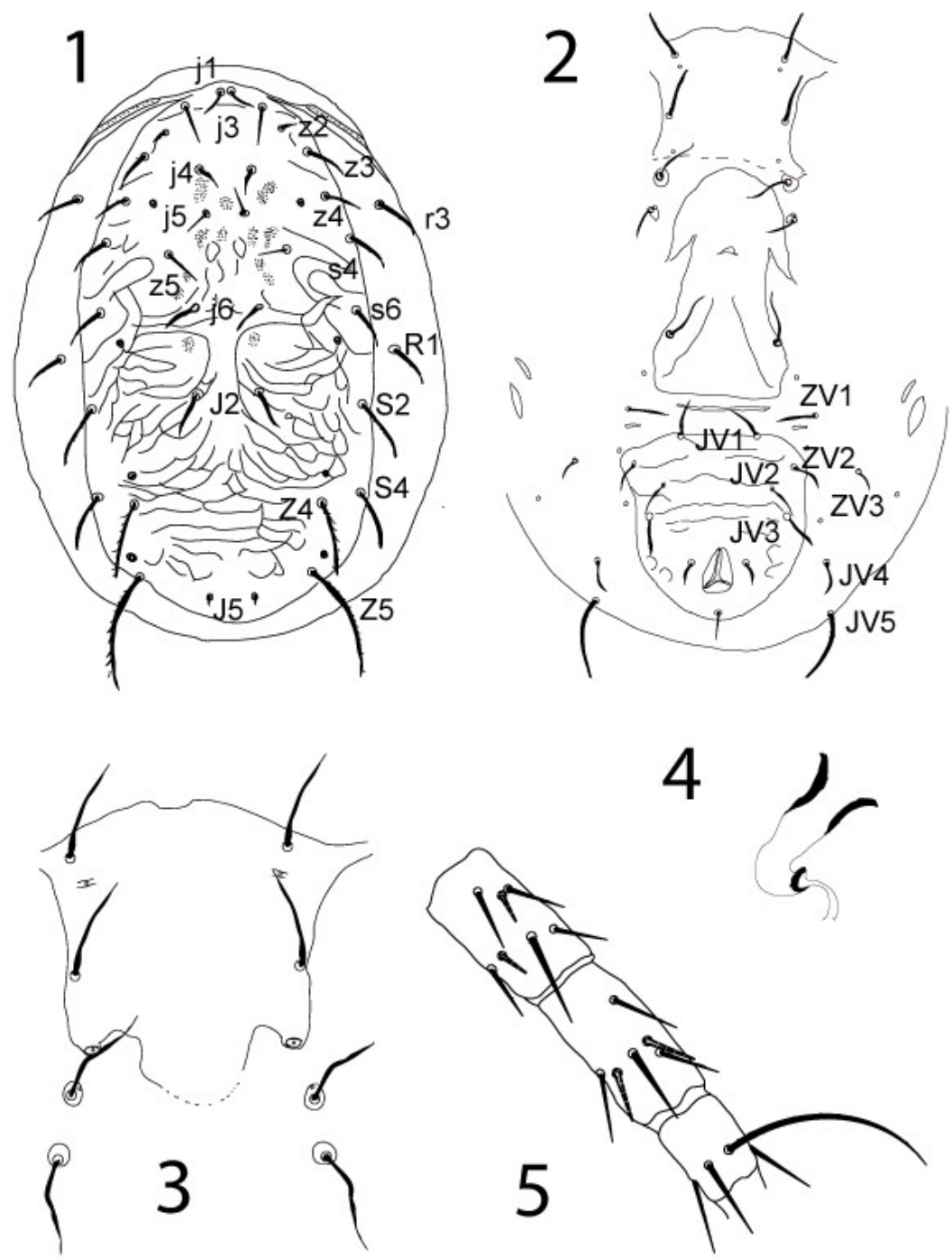

FIGURE 2

Typhlodromus (typhlodromus) spiceae sp.n. with dorsal (1) and ventral (2) view of idiosoma. Spermatheca (4) and genu, tibia and tarsus of leg IV (5).

Chelicerae. The position of the chelicerae renders an illustration impossible, but movable digit apparently with 2 teeth and fixed digit with 4 teeth and a pilus dentilis.

Legs (Fig. 2 (5); Table 1): Macrosetae sharp-tipped: Sge IV 25, Sti IV 25, St IV 46 (42 - 50). Chaetotaxy: genu II 2-2/0, 2/0-1; genu III: 1-2/1, 2/0-1.

\section{Type material}

The holotype female and five paratype females were collected from Vitis vinifera L. Two females were collected near Wellington (34 24 '1.50" S; $19^{\circ} 13^{\prime} 43.13$ " E) in a mother block. The other five females were also collected near Wellington, but in a commercial vineyard. All specimens were collected by the first author.

\section{DISCUSSION}

This new species, Typhlodromus (Typhlodromus) spicae sp.n., belongs to a group of species with 4 pairs of solenostomes (gd2, gd6, gd8, gd9) on the dorsal shield, ventrianal shield pentagonal and without preanal pores. We reduced the 29 species with similar characters to 23 based on synonyms and possible synonyms suggested in Ferragut \& Ueckermann (2012); Stathakis et al. (2012); and Tixier et al. (2016).

Typhlodromus (T.) spiceae sp.n. differs from the other 23 species as follows: T. (T.) octogenipilus Kreiter et al., T. (T.) sirikariensis Stathakis et al., T. (T.) antakyensis Stathakis et al. and T. (T.) mazarii Allam et al. have eight setae on genu II (seven in new species). T. (T.) setubali Dosse and T. (T.) moroccoensis Denmark have six setae on genu II. In $T$. (T.) laurae Arutunjan and T. (T.) knisleyi Denmark setae $\mathrm{Z} 4$ are 0.5 times the length of Z5, but in $T$. (T.) spicae sp.n. $\mathrm{Z} 4$ is about 0.7 times the length of Z5. It also differs from these two species in the shape of the spermatheca, which is saccular and thick walled in the two species, but tube-like/ saccular with only distal half thick walled in the new species.

The calyx of the spermatheca of $T$. (T.) personatus Karg, T. (T.) bichaetae Karg and T. (T.) cotoneastri Wainstein is proximally slender, tube-like and flared distally, but in the new species it is saccular/tube-like with only distal half thick walled. Calyx of spermatheca of $T$. (T.) exhilaratus Ragusa and T. (T.) atlanticus Ferragut with a short neck and small bulbous atrium, setae $\mathrm{j} 1$ and $\mathrm{j} 3$ subequally long and 
TABLE 1

Comparisons between measurements (in $\mu \mathrm{m}$ ) of the specimens (total six, all female) of Typhlodromus (typhlodromus) spiceae sp.n.

\begin{tabular}{|c|c|c|c|c|c|c|}
\hline & Holotype & $\begin{array}{l}\text { Para species (Female) } \\
\text { (slightly damaged) }\end{array}$ & para $(\mathrm{F})$ & para $(\mathrm{F})$ & para $(\mathrm{F})$ & para $(\mathrm{F})$ \\
\hline Length of dorsal shield & 322 & 317 & 316 & 330 & 318 & 306 \\
\hline Width of dorsal shield & 162 & 174 & 167 & 168 & 181 & 160 \\
\hline st1 - st2 & 31 & 37 & 35 & 31 & 34 & 32 \\
\hline st2 - st2 & 57 & & 56 & 60 & 61 & 60 \\
\hline st5 - st5 & 54 & 58 & 60 & 56 & 55 & 55 \\
\hline Ventral anal plate & 96 & 108 & 105 & 103 & 107 & 140 \\
\hline B. Zv2 - Zv2 & 84 & 87 & 85 & 99 & 89 & 92 \\
\hline B. Anal opening & 77 & 74 & 81 & 84 & 85 & 88 \\
\hline JV5 & 60 & 63 & 61 & 58 & 54 & 57 \\
\hline st IV & 46 & 47 & 43 & 50 & 42 & 52 \\
\hline sti IV & 25 & 24 & 24 & 24 & 24 & 28 \\
\hline sge IV & 25 & 23 & 23 & 27 & 25 & 24 \\
\hline $\mathrm{j} 1$ & 22 & 23 & 20 & 19 & 20 & 19 \\
\hline j3 & 31 & 31 & 31 & 32 & 30 & 32 \\
\hline j4 & 16 & 18 & 17 & 19 & 17 & 20 \\
\hline $\mathrm{j} 5$ & 16 & 18 & 20 & 19 & 18 & 18 \\
\hline $\mathrm{j} 6$ & 22 & 22 & 23 & 23 & 19 & 22 \\
\hline $\mathrm{J} 2$ & 20 & 23 & 24 & 24 & 25 & 24 \\
\hline $\mathrm{z} 2$ & 22 & 18 & 18 & 19 & 19 & 18 \\
\hline $\mathrm{z} 3$ & 26 & 28 & 23 & 29 & 26 & 27 \\
\hline $\mathrm{z} 4$ & 24 & 26 & 27 & 26 & 25 & 31 \\
\hline s4 & 30 & 32 & 33 & 33 & 33 & 31 \\
\hline s6 & 35 & 34 & 34 & 38 & 38 & 37 \\
\hline S2 & 39 & 41 & 41 & 40 & 39 & 43 \\
\hline S4 & 41 & 40 & 46 & 41 & 43 & 40 \\
\hline $\mathrm{Z} 4$ & 47 & 50 & 55 & 50 & 48 & 47 \\
\hline $\mathrm{Z5}$ & 69 & 71 & 69 & 71 & 70 & 69 \\
\hline $\mathrm{J} 5$ & 5 & 6 & 6 & 7 & 6 & 7 \\
\hline $\mathrm{z} 5$ & 19 & 20 & 18 & 19 & 19 & 20 \\
\hline r3 & 21 & 22 & 25 & 27 & 28 & 27 \\
\hline $\mathrm{R} 1$ & 30 & 26 & 24 & 26 & 25 & 26 \\
\hline Spermatheca & 15 & 16 & 16 & 15 & 16 & 15 \\
\hline
\end{tabular}

peritreme reach to level between setae $\mathrm{j} 1$ and $\mathrm{j} 3$, but, in the new species the atrium is incorporated in the saccular calyx, setae $\mathrm{j} 3$ are longer than $\mathrm{j} 1$ and the peritreme reach to between $j 3$ and z2. Typhlodromus (T.) atlanticus further differs in that setae Z4 are clearly shorter than distance to Z5 and the latter two setae are also shorter than those in the new species, $27-$ 33 and $36-41$ versus $47-55$ and 69-71, respectively. Calyx of spermatheca of $T$. (T.) beglarovi Kuznetzov and T. (T.) olympicus Papadoulis \& Emmanouel is also with a short neck and small bulbous atrium which differs from that of the new species as already mentioned previously. Both these two species further differ from $T$. (T.) spiceae sp.n. in that setae Z4 are clearly shorter than the distance to setae Z5, instead of extending to Z5. Thus, the distance between Z4 
and $\mathrm{Z} 5$ are greater compared to other species where there is little difference in length between Z4 and Z5. The following nine species resemble the new species in that the calyx of the spermatheca is without a neck or constriction between it and the atrium. However, T. (T.) klimenkoi, Kolodochka differs from them all in the short peritreme reaching to a level between setae $z 3$ and $z 4$ and in that the peritreme is not uniformly stippled but only with a central core. Typhlodromus (T.) tiliae Oudemans differs from the new species in that setae Z4 is shorter than the distance to Z5 and peritreme reach to a level between $\mathrm{z} 2$ and $\mathrm{z} 3$ (j3 and z2 in new species). Typhlodromus (T.) floresiensis Ferragut, $T$. (T.) morelllensis Ferragut and T. (T.) mutatus Kolodochka can be distinguished from the new species in that setae Z4 are also shorter than distance to Z5 and setae Z4 and Z5 are clearly shorter, 40 (19-30) and 70 (36-47), respectively. The bell-shaped calyx of the spermatheca, setae $\mathrm{j} 1$ and $\mathrm{j} 3$ equally long and shorter setae Z4 (33-36 vs 47-55) and Z5 (50-54 vs 69-71) distinguish $T$. (T.) erensti Ragusa \& Swirski from the new species.

The peritreme extending to between setae $\mathrm{j} 1$ and $\mathrm{j} 3$ versus $\mathrm{j} 3$ and z2 in new species, shorter setae Z4 (38 vs 4755 ) and Z5 (54 vs 69-71) and short, broad, thick walled and tubular calyx of spermatheca of $T$. (T.) phialatus, AthiasHenriot separate it from the new species. The new species, however, is similar to T. (T.) athiasae Porath \& Swirski, but the long, thick-walled tubular calyx of the spermatheca distinguishes it from $T$. (T.) spiceae sp.n., only the distal half of the calyx of the latter is thick walled.

Typhlodromus (Typhlodromus) spiceae specimens were collected together with other phytoseiidae, namely Typhlodromus praeacutus preaecutus van der Merwe, Typhlodromus saevus van der Merwe and Euseius rubicolus (Van der Merwe \& Ryke),) as well as a phytophagous mite, Brevipalpus lewisi McGregor (Tenuipalpidae). The fact that is was found on only two of the four farms sampled and that it was less abundant than the other phytoseiid species in the mite samples may explain why it has only now been identified. Another contributing factor is that farmers and pest management consultants generally only note the presence of predatory mites when monitoring pests on grapevines and do not bother to identify individual species.

Many factors play a role in mite predator colonialization of grapevines. It has been shown that grapevine leaf morphology influences predator settlement and can therefore affect interspecific competition (Duso \& Vettorazzo, 1999). This aspect was not investigated in this survey. The type of adjacent vegetation that provide a refuge in winter during grapevine dormancy can also influence which predatory mite species occur and even their relative abundance (Sentenac, et al., 2002). The vegetation adjacent to the vineyards sampled in this survey was not specifically identified or sampled, therefore no conclusions can be drawn regarding the influence of this vegetation on the species composition or relative abundance in the sampled vineyards. Winter cover crops in vineyards can also provide refuges for predatory mites during grapevine dormancy. In view of the findings of other research, e.g. Sentenac, et al. (2002), the type of cover crop, the presence or absence of prey species on the cover crops and predatory mite species prey preference will determine the role that cover crops play in maintaining predatory mite populations in vineyards.

In the South African context, the identification of a new predatory mite, Typhlodromus spicieae, is important because the benefits for biocontrol of having a complex of predatory mite species versus a single species has been demonstrated. Interspecific competition between predators tend to have a healthy outcome on predator prey dynamics within the community, as the coexistence of two or more predators in a community enhances the chances of controlling a pest (McMurtry et al., 1970; Croft \& McRae, 1992; Rosenheim et al., 1995). Phytoseiid mites are categorized according to food preference, which consists of four main catagories (McMurtry \& Croft, 1997; McMurtry et al., 2013). The genus Typhlodromus tend to be either Type Ib or IIIa. Type IIIa are considered generalists that feed on mites that prefer a habitat of pubescent leaves, while type $\mathrm{Ib}$ are specialist precators of web-producing Tetranychidae (McMurtry et al., 2013). Eusieus De Leon live according to the type IV lifestyle - pollen feeding generalist predators (McMurtry et al., 2013). The predatory mites found with $T$. spiceae vary between Tetranychidae specialists (Type Ib) and generalist feeders (Type Ia). Based on current information, it is not possible to determine the feeding habitat of $T$. spiceae.

Brevipalpus lewisi is a new grapevine pest in the Western Cape (Saccaggi \& Ueckermann, 2018). At present it is unclear what its predators are (Saccaggi et al., 2017) and if T. spicieae could potentially be preying on $B$. lewisi.

The persistence of different predatory species in a vineyard confirm that they have the capacity to survive on a variety of prey, successfully propagate and compete with other predatory mites (Duso \& Vettorazzo, 1999). No miticides were applied in the vineyards used for this survey and the only mite prey species present in the samples was B. lewisi. This, together with the abundance of predatory mites in the samples of this survey indicate that phytophagous mites such as Tetranychidae were being suppressed to undetectable levels.

Further research is required to determine what $T$. spiceae feeds on, as this will indicate its role in biocontrol, and more extensive surveys are needed to establish its distribution on grapevines in South Africa. Knowledge about the population dynamics of Phytoseiidae in South African vineyards is limited and aspects that need investigation include the effect of adjacent vegetation and cover crops on species composition and relative abundance of predatory mite populations in vineyards.

\section{Etymology}

This species name refers to the cat, Spice, of the senior author.

Key to South African species of Typhlodromus (Typhlodromus) - Females

1. Preanal pores absent; dorsal setae short and mostly smooth

Preanal pores present; dorsal setae long and mostly serrate T. (T.) magdalenae Pritchard \& Baker 
2. Dorsal shield with 5 solenostomes; setae Z4 smooth; peritreme extending to a level between setae $\mathrm{j} 1$ and $\mathrm{j} 3$; ventrianal shield clearly narrower across anal opening; macroseta on tarsus IV (St) $24 \quad T$. (T.) griekwensis Schultz

- Dorsal shield with 4 solenostomes; setae Z4 serrate; peritreme extending to a level between setae $z 2$ and $j 3$; ventrianal shield almost squarish; macroseta on tarsus IV (St) 46

T. (T.) spiceae sp.n.

\section{LITERATURE CITED}

Annecke, D.P. \& Moran, V.C., 1982. Insects and Mites of Cultivated plants in Southern Africa. Butterworths, Durban.

Aratchige, N.S., Lesna, I. \& Sabelis, M.W., 2004. Below-ground plant parts emit herbivore-induced volatiles: olfactory responses of a predatory mite to tulip bulbs infested by rust mite. Exp. Appl. Acarol. 43, 97 - 107.

Botha, J.H., 1993. Infruitec manual for identification of good bugs in deciduous fruit orchards. Infruitec, Stellenbosch.

Botha, J.H., Van Ark, H. \& Scholtz, A.J., 1986. The effect of bollworm with regard to populations of spider mites and some of their natural enemies on cotton. Phytophylactica 18, $141-150$.

Chant, D.A. \& Yoshida-Shaul, E., 1992. Adult idiosomal setal patterns in the family Phytoseiidae review (Acari: Gamasina). Int. J. Acarology 18(3), $177-193$.

Childers, C.C., French, J.V. \& Rodrigues, J.C.V., 2003. Brevipalpus californicus, B. obovatus, B. phoenicis and B. lewisi (Acari: Tenuipalpidae): a review of their biology, feeding injury and economic importance. Exp. Appl. Acarol. 30, 5-28.

Coates, T.J.D., 1974. The influence of some natural enemies and pesticides on various populations of Tetranychus cinnabarinus (Boisduval), T. lombardinii Baker \& Pritchard and T. ludeni Zacher (Acari: Tetranychidae) with aspects of their biologies. Entomology Memoir 42, Department of Agricultural Technical Services, Pretoria.

Croft, B.A., 1990. Arthropod Biological Control Agents and Pesticides. Wiley, New York, NY.

Croft, B.A., Blackwood, J.S. \& McMurty, J.A., 2004. Classifying life-style types of phytoseiid mites: diagnostic traits. J. Appl. Entomol 33, $247-260$.

Croft, B.A., Kim, S.S. \& Kim, D.I., 1995. Leaf residency and interleaf movement of four phytoseiid mites (Acari: Phytoseiidae) on apple. Environ Entomol 24(5), $1344-1351$.

Croft, B.A. \& McRae, I.V., 1992. Biological control of apple mites by mixed populations of Metaseiulus occidentalis (Nesbitt) and Typhlodromus pyri Scheuten (Acari:Phytoseiidae). Environ. Entomol 21, 202 - 209.

Croft, B. A., Moretti, L. N. Pratt, P. D., 1998. Comparative life histories and predation types: are Neoseiulus fallacis (Acari: Phytoseiidae) similar type II selective predators of spider mites? Environ Entomol. 27, 531 - 538.

Demite P.R., Moraes G.J. de, McMurtry J.A., Denmark H.A. \& Castilho R.C., 2020. Phytoseiidae Database. Available from: www.lea.esalq.usp.br/ phytoseiidae (last accessed 20/03/2020).

Demite, P.R., McMurtry, J.A. \& de Moraes, G.J., 2014. Phytoseiidae database: A website for taxonomic and distributional information on phytoseiid mites (Acari). Zootaxa 3795 (5), 571 - 577.

De Moraes, G.J., McMurtry, J.A., Denmark, H.A. \& Campos, C.B., 2004 A revised catalog of the mite family Phytoseiidae. Zootaxa 434, 1- 494.

Desneux, N., Decourtye, A. \& Delpuech, J.M., 2007. The sublethal effects of pesticides on beneficial arthropods. Annu. Rev. of Entomol 52, 81 - 106.
Dicke, M., 1988. Prey preference of the phytoseiid mite Typhlodromus pyri: 1. Response to volatile kairomone. Exp. Appl Acarol. 4, 1 - 13.

Dicke, M., Sabelis, M.W. \& de Jong, M., 1988. Analysis of prey preference in phytoseiid mites using an olfactometer, predation models and electrophoresis. Exp. Appl. Acarol. 5, 225 - 241.

Duncombe, W.G., 1977. Cotton losses caused by spider mites (Acarina: Tetranychidae) Rhodesia Agricultural Journal 74, 141 - 146

Duso, C. \& Vettorazzo, E., 1999. Mite population dynamics on different grape varieties with or without phytoseiids released (Acari: Phytoseiidae). Exp. Appl. Acarol 23, 741 -763.

Duso, C. \& Pasqualetto, C., 1993. Factors affecting the potential of phytoseiid mites (Acari: Phytoseiidae) as biocontrol agents in north Italian vineyards. Exp Appl Acarol 17, 241-258.

Duso, C., 1989. Role of Amblyseius aberrans (Oud). Typhlodromus pyri Scheuten and Amblyseius andersoni (Chant) (Acari:Phytoseiidae) in vineyards. I. The effect of single or mixed phytoseiid population releases on spider mite densities (Acari, Tetranychidae). J. Appl. Entomol. 107, 474 -492 .

Duso, C., Fontana, P., D’Ascenzio, D. \& Di Silvestro, D., 1994. Idagini preliminary sulla diffusione degli Acari Fitoseidi (Acari Phytoseiidae) nei vigneti abruzzes I. Alti Giornate Fitopatologiche 1994, 2, 219-226.

Duso, C., Pozzebon, A., Kreiter, S., Tixier, M.S. \& Candolfi, M. P., 2012. Management of phytophagous mites in European vineyards. In: Bostanian N.J., Vincent C., and Isaacs R. (Eds). Arthropod management in vineyards: pests, approaches, and future directions. Springer, 191-217.

Du Toit, C.L.N., 1993. 'n Elektroniese studie van Tetranychus evansi Baker \& Pritchard op Tabak met Spesialie Verwysing na die Geïntegreerde Beheeer en Ekonomiese Belangrikheid daarvan. PhD thesis, University of Johannesburg, PO Box 524, Auckland Park, 2006, South Africa.

Engel, R. \& Ohnesorge, B., 1994a. Die Rolle von Ersatznahrung und Mikroklima im System Typhlodromus pyri Scheuten (Acari, Phytoseidae) - Panonychus ulmi Koch (Acari,Tetranychidae) auf Weinreben I. Untersuchungen im Labor. J. Appl. Entomol. 118, 129-150.

Engel, R. \& Ohnesorge, B., 1994b. Die Rolle von Ersatznahrung und Mikroklima im System Typhlodromus pyri Scheuten (Acari, Phytoseidae) - Panonychus ulmi Koch (Acari,Tetranychidae) auf Weinreben I. Freilandversuche. J. Appl. Entomol. 118, 224-238.

Escudero, L.A. \& Farragut, F., 2005. Life history of predatory mites Neoseiulus californicus and Phytoseiulus persimilis (Acari: Phytoseiidae) on four spider mite species as prey, with special reference to Tetranychus evansi (Acari: Tetranychidae). Biol. Control 32, 378 - 384.

Evans, G. O., 1992. Principles of Acarology. Commonwealth Agricultural Bureau (CAB) International Oregon State University: Cordley Hall.

Ferragut, F. \& Ueckermann, E.A., 2012. A new species and new records of the subgenus Typhlodromus Scheuten from Spain, with a key to the world species (Acari: Phytoseiidae). J. Nat. Hist. 46(27-28), 1731-1745.

Flaherty, D.L. \& Wilson, L.T., 1999. Biological control of insects and mites on grapes. Bellows, T. S. \& Fisher, T. W. (Eds). Handbook of biological control. Academic press, New York.

Fraulo, A.B. \& Liburd, O.E., 2007. Biological control of two-spotted spider mite, Tetranychus urticae, with predatory mite, Neoseiulus califronicus in strawberries. Exp. Appl. Acarol. 43, 109 - 119.

Gerson, U., Smiley, R.L. \& Ochoa, R., 2003. Mites (Acari) for Pest Control. Blackwell Publishing, Oxford.

Girolami, V., Picotti, P. \& Coiutti, C., 1992. Ruolo determinante del f toseide Amblyseius aberrans (Oud.) nel controllo degli acari f tofagi. L'Informatore Agrario 68, 65-69. 
Greco, N.M., Sanchez, N.E. \& Liljesthrom, G.G., 2005. Neoseiulus californicus (Acari: Phytoseiidae) as a potential control agent of Tetranychus urticae (Acari: Tetranychidae): effect of pest predator ratio on pest abundance on strawberry. Exp. Appl. Acarol. 37, 57 - 66

Hao, D.J., Su, P., Pfammatter, J., Lui, Q., Fan, B.Q., Wang, Y. \& Gu, T.Z., 2016. Morphological and genetic characteristics of Brevipalpus lewisi (Acari: Tenuipalpidae) and comparison with other three Brevipalpus species. Int. J. of Acarol. 42, 1, 34 - 40.

Helle, W. \& Sabelis, M.W. (Eds). 1985a. Spider mites: Their Biology, Natural Enemies and Control (1A Edition). Elsevier, New York.

Helle, W. \& Sabelis, M.W. (Eds). 1985b. Spider mites: Their Biology, Natural Enemies and Control (1B Edition). Elsevier, New York.

Hislop, R.G. \& Jeppson, L.R., 1976. Morphology of the mouthparts of several species of phytophagous mites. Ann. Entomol. Soc. Am. 59, 1125 -1135 .

Ivancich Gambaro, I., 1973. Il ruolo del Typhlodromus aberrans Oudemans (Acarina Phytoseiidae) nel controllo biologico degli Acari fitofagi del Veronese. Boll Zool Agrar Bachic 11, 151 - 165.

James, D.G. \& Whitney, J., 1993. Mite populations on grapevine in Southeastern Australia: implications for biological control of grapevine mites (Acarina: Tenuipalpidae, Eriophyidae). Exp. Appl. Acarol. 17, 259 - 270.

James, D.G., 1990. Biological control of Tetranychus urticae (Koch) (Acari: Tetranychidae) in southern New South Wales peach orchards: the role of Amblyseius victoriensis (Acarina: Phytoseiidae). Aust. J. Zool. 37, $645-$ 655 .

Jeppson, L.R., Keifer, H.H. \& Baker, E.W., 1975. Mites Injurious to Economic Plants. Berkeley, California.

Johnsen, S. \& Hansen, E. W., 1986. Control of the spider mite Panonychus ulmi by Typhlodromus pyri, some details. Bulletin OILB-SROP 9(4), 34 37.

Jung, C. \& Croft, B.A., 2001. Ambulatory and aerial dispersal among specialist and generalist predators. Biol. Control 32, $243-251$.

Krantz, G.W. \& Walter, D.E., 2009. A Manual of Acarology. Texas Tech University Press, Lubbock, Texas.

Kreiter, S., Tixier, M-S., Auger, P., Muckensturm, N., Sentenac, G., Doublet, B. \& Weber, M., 2000. Phytoseiid mites of vineyards in France. Acarologia $41,77-96$

Liguori, M., 1988. Effetto di trattamenti antiparassitari diversi sulle popolazioni del $\mathrm{f}$ toseide predatore Typhlodromus exhilaratus Ragusa e su quelle degli acari $\mathrm{f}$ tofagi in un vigneto del senese. Redia 71, 455-462.

Lindquist, E. \& Evans, G.W., 1965. Taxonomic concepts in the Ascidae, with a modified setal nomenclature for the idiosoma of the Gamasina Acarina: Mesostigmata. Mem. Ent. Soc. Can. 47, 1-64.

Lindquist, E.E., 1998. Review: Evolution of phytophagy in Trombidiform mites. Exp. Appl. Acarol. 22(2), 81 -100.

Lindquist, E.E., Sabelis, M.W. \& Bruin, J., 1996. Eriophyoid Mites, Their Biology, Natural Enemies and Control. Elsevier Academic Press, Amsterdam.

Mani, M., Shivaraju, C. \& Rao, M.S., 2014. Pests of Grapevine: a worldwide list. Pest Manag. Hort. Ecosyst. 20(2), 170 - 216.

McMurtry, J. A., 1982. The use of phytoseiids for biological control: progress and future prospects. Hoy, M. A. (Ed). Recent Advances in Knowledge of The Phytoseiidae. Berkley, California.

McMurtry, J.A., 1992. Dynamics and potential impact of 'generalist' phytoseiids in agroecosystems and possibilities for establishment of exotic species. Exp. Appl. Acarol. 14, 371 - 382.
McMurtry, J.A. \& Croft, B.A., 1997. Lifestyles of phytoseiid mites and their roles in biocontrol. Annu. Rev. Entomol. 42, 291 - 321.

McMutry, J.A., de Moraes, G.J. \& Sourassou, N.J., 2013. Revision of the lifestyles of phytoseiid mites (Acari: Phytoseiidae) implications for biological control strategies. Syst. Appl. Acarol. 18, 297 - 320.

McMurtry, J.A., Huffaker, C.B. \& Van de Vrie, M., 1970. Ecology of tetranychid mites and their natural enemies, a review. Tetranychid enemies, their biological characteristics and the impact of spray practices. Hilgardia $40,331-390$

Moutia, L.A., 1958. Contribution to the study of some phytophagous Acarina and their predators in Mauritius. Bull. Entomol. Res. 49, 59 - 75.

Nyrop, J., English-Loeb, G. \& Roda, A., 1998. Conservation biological control of spider mites in perennial cropping systems. Barbosa, P. (Ed). Conservation biological control. Academic Press, San Diego.

Pozzebon, A. \& Duso, C., 2008. Grape downy mildew Plasmopara viticola an alternative food for generalist predatory mites occurring in vineyards. Biol. Control 45, 441 - 449 .

Pozzebon, A., Loeb, G.M., \& Duso, C., 2009. Grape powdery mildew as a food source for generalist predatory mites occurring in vineyards: effects on life-history traits. Ann. Appl. Biol 155(1), 81 - 89.

Pringle, K.L., Rust, D.J. \& Meyer, M.P.K., 1986. Plant-eating mites. Myburgh, A. C. (Ed). Crop pests in southern Africa, vol 1. Deciduous fruit, grapes and berries Pretoria, Plant protection institute, Department of Agriculture and Water supply.

Ripka, G. 1998., New data to the knowledge on the phytoseiid fauna in Hungary (Acari: Mesostigmata). Acta Phytopathol. Entomol. Hung. 33, 395 -405 .

Rosenheim, J.A., Kaya, H.K., Ehler, L.E., Marois, J.J. \& Jaffee, B.A., 1995. Intraguild predation among biological-control agents: theory and evidence. Biol. Control, 5:303 - 335.

Rowell, H.J., Chant, D.A. \& Hansell, R.I.C., 1978. The determination of setal homologies and setal patterns on the dorsal shield in the family Phytoseiidae (Acarina: Mesostigmata). Canadian Entomologist 110, 859876.

Sabelis, M.W. \& Dicke, M., 1985. Long-range dispersal and searching behaviour. Helle, W \& Sabelis, M.W. (Eds). Spider mites, their biology, natural enemies and control, vol 1B. Elsevier, Amsterdam.

Saccaggi, D.L. \& Ueckermann, E.A., 2018. Agistemus collyerae (Acari: Trombidiformes: Stigmaeidae) in South Africa: first record, introduction pathways and re-description including additional life stages. Acarologia $58(1), 116-130$.

Saccaggi, D.L., Ueckermann, E.A., du Toit, I. \& Ngubane-Ndlovu, N.P., 2017. First records of Brevipalpus lewisi McGregor (Acar: Trombidiformes: Tenuipalpidae) in South Africa, with notes on distribution and field ecology. Afr. Entomol. 25(2), 523 - 528 .

Sentenac, G., Bonafos, R., Ruelle B., Coulon, T., Escalfre, P., Auger, P. \& Kreiter, S., 2002. Effects non intentionels de certains produits phytopharmaceutiques sur Typhlodromus pyri, Kampimodromus aberrans et Phyoseius plumifer. Phytoma 555, 50 -55.

Sentenac, G., Kreiter, S., Weber, M., Barthes, D., Jacquet, C., 1993. Protection integrec vountre les acariens de la vigne. International Congress Euroviti. $7^{\text {th }}$ I.T.V. Latles $135-174$. Transcomp Montepellier Publisher, Montepellier.

Smith Meyer, M.K.P., 1974. The Tenuipalpidae (Acari) of Africa. With keys to the world fauna. Entomology Memoir, 50. Department of Agricultural Technical Services, Pretoria.

Smith Meyer, M. K. P., 1979. The Tenuipalpidae (Acari) of Southern Africa. With keys to the world of fauna. Entmology Memoir, 50. Department of Agricultural Technical Services, Pretoria. 
Smith Meyer, M.K.P., 1981. Mite pests of crops in Southern Africa. Science Bulletin, 397. Department of Agriculture and Fisheries, Pretoria.

Smith Meyer, M.K.P., 1987. African Tetranychidae (Acari: Prostigmata), with reference to the world genera. Entomology memoir 69, Department of Agriculuture and water supply, Pretoria.

Smith Meyer, M.K P., 1996. Mite pests and their predators on cultivated plants in Southern Africa. Vegetables and berries. Agricultural Research Council.

Smith Meyer, M.K.P. \& Craemer, C., 1999. Mites (Acarina: Acari) as crop pests in Southern Africa: An overview. Afr. Plant Prot. 5(1), 37 - 51.

Smith Meyer, M.K.P. Daiber, K.C., Pringle, K.L., Rust, D.J. \& Myburgh, A.C., 1990. Plant-feeding mites. In: Crops pests in Southern Africa, vol. 5. Flowers and other ornamentals, 67 - 74 (Ed. A. C. Myburgh) Bulletin 419 , Department of Agricultural Development, Pretoria.

Smith Meyer, M. K. P., Eulitz, E. G., Walters, S. S. \& Myburgh, A. C., 1989 Crop pests in Southern Africa, vol 4. Field crops and pastures. Myburgh, A

C. (Ed). Bulletin 416, Department of agriculture and water supply, Pretoria.

Smith Meyer, M.K.P., Fourie, P.F. \& Petty, G.I., 1987. Plant-eating mites. Myburgh, A.C. (Ed). Crop Pests of Southern Africa, vol. 2. Citrus and Other Subtropicals. Bulletin 411, Department of agriculture and water supply, Pretoria.

Smith Meyer, M.K.P. \& Rodrigues, M.C., 1966. Acari associated with cotton in southern Africa (with reference to other plants). Garcia de Orta $13,1-33$.

Smith Meyer, M. K. P. \& Schwartz, A., 1998. Order Acari: mites and ticks Family Tenuipalpidae: flat mites. Reddish-black flat mite (Brevipalpus phoenicis (Geijskes)) In: Citrus pests in the republic of South Africa, 74 77. E. C. G. Bedford, M. A. van den Berg \& E. A. de Villiers (Eds). ARC - Institute for Tropical and Sub-tropical Crops, Nelspruit.
Solomon, M.M., Easterbrook, M.A. \& Fitzgerald, J.P., 1993. Mite management programmes based on organophosphate-resistant Typhlodromus pyri in the United Kingdom apple orchards. J. Econ. Entomol. 76, 6-10.

Stathakis, T.I., Kapaxidi, E.V. \& Papadoulis, G.T., 2012. A new record and two new species of the genus Typhlodromus Scheuten (Acari: phytoseiidae) from Greece. Int. J. Acarol. 38(7), 605 - 611.

Tixier, M.-S., Allam, L., Douin, M. \& Kreiter, S., 2016. Phytoseiidae (Acari: Mesostigmata) of Morocco: new records, descriptions of five new species, re-description of two species, and key for identification. Zootaxa 4067 (5), 501-551.

Tixier, M.S., Baldassar, A., Duso, C. \& Kreiter, S., 2013. Phytoseiidae in European grape (Vitis vinifera L.): bio-ecological aspects and keys to species (Acari: Mesostigmata). Zootaxa 3721, 101-142.

Walter, D.E. \& Proctor, H.C., 2013. Mites: Ecology, Evolution \& Behaviour. Life at Microscale. Springer, New York.

Walter, D.E., 2004. Hidden in plain sight: Mites in the canopy. (Eds), Lowman, M.D. \& Brinker, H.B. Forest Canopies. Elsevier, Amsterdam.

Walter, D.E., Lindquist, E.E., Smith, I.M., Cook, D.R. \& Krantz, G.W. 2009. Order Trombidiformes. Krantz, G. W. \& Walter, D. E. (Eds). A manual of acarology. Texas Tech University Press, Texas.

Wearing, C.H., Walker, J.T.S., Collyer, E. \& Thomas, W.P., 1978. Integrated control of apple pests in New Zealand. 8. Control assessment of an integrated programme against European red mite using an insecticideresistant predator. N. Z. J. Zool. 5, 823-837. 